\title{
Preparation of Activated Carbon from Date Seeds and Evaluation of Its Applications
}

\author{
Kawthar Al-Balushi ${ }^{1}$, Subramanyam Revanuru ${ }^{2}$ and Sreedhar Reddy Sajjala
}

\begin{abstract}
Activated carbon (AC) is frequently used for purification due to its ability to remove pollutants either from air or water. Its porous structure allowed it to capture the pollutants and is widely recommended for numerous applications in water and wastewater treatment. However, AC application fields are restricted due to high cost. In this project, AC prepared from locally available date seeds is used for the removal of Methylene blue (MB) from aqueous solution, in order to find alternative to commercial activated carbon (CAC). Physical properties of date seeds activated carbon (DSAC) and CAC were compared and batch adsorption processes were obtained to find the best condition for using DSAC in the removal of MB. The experimental outcomes found that DSAC got high percentage removal and it has a good potential for economic removal of MB.
\end{abstract}

Keywords-Activated carbon, Date seeds activated carbon, Adsorption, Methylene blue, Langmuir isotherm, Freundlich isotherm.

\section{INTRODUCTION}

There are large numbers of palm trees in Oman and thus the amount of dates are largely available, which is economically viable material for the production of activated carbon (AC) from date seeds (DS). The date seeds activated carbon (DSAC) is also used as a filtering medium for automobiles exhaust gases and as an adsorbent of toxic organic and inorganic compounds [1]. Carbon adsorption has numerous applications in removing pollutants e.g. color water streams both in the field and in industrial processes such as spill cleanup, groundwater remediation and drinking water filtration. However, its application fields are restricted due to high cost. Discharge of dyes in to effluents affects the people who may use these effluents for living purposes such as washing, bathing and drinking [2]. The conversion of waste materials and agriculture by-products, into ACs would add considerable economic value, help reduce the cost of waste disposal and most importantly provide a potentially inexpensive alternative to the existing commercial activated carbon (CAC) [3]. The present work deals with preparation of DSAC and verify its efficiency in removal of methylene blue (MB) from aqueous solutions and to compare the results with the CAC.

Department of Civil and Environmental Engineering, College of Engineering and Architecture, University of Nizwa (UoN), Initial Campus at Birkat al Mouz, P.O. Box 33, P C 616, Nizwa, OMAN

\section{II.EXPERIMENTAL}

\subsection{Materials and Methods}

The DS was collected from locally available dates in Oman. The MB (Scharlau) concentration used was $0.995 \mathrm{~g} / \mathrm{ml}$. It has a molecular weight of $319.86 \mathrm{~g} / \mathrm{mol}$, density of $0.995 \mathrm{~g} / \mathrm{cm}^{3}$, molecular formula is $\mathrm{C}_{16} \mathrm{H}_{18} \mathrm{CIN}_{3} \mathrm{~S}$. The $\mathrm{MB}$ and all other chemicals, such as $\mathrm{NaOH}$ and $\mathrm{HCl}$, were laboratory grade. The instruments used for DSAC preparation were: muffle furnace (Nabertherm more than heat $30-3000{ }^{\circ} \mathrm{C}$ ), conductivity meter (Elico, CM183EC-TDS Analyser) and digital magnetic stirrer (WiseStir MS-D-Digital magnetic stirrer). A spectrophotometer (Spectronic BioMate 5 UV-Visible Spectrophotometers) used to find $\lambda_{\max }$ for MB and for absorbance determination. Filter papers were used to remove the AC from the solution before determining the absorbance from the spectrophotometer. The standard test method ASTM-D3838 -80 was used [4] to determine the $\mathrm{pH}$ of $\mathrm{AC}$ by using $\mathrm{pH}$ meter (Eutech instruments, CyberScan pH 300). The samples were tested in duplicates. Determination of moisture content was according to ASTM -D1762 [5]. In determining the ash content, $0.1 \mathrm{~g}$ of the AC heated at $500{ }^{\circ} \mathrm{C}$ for 4 hours, cooled in a desiccator and weigh [6].

\subsubsection{Preparation of AC from $D S$}

DS are used for the preparation of AC. Many researchers used different methodologies to prepare DSAC. According to [7] research, the following procedure is considered.

\subsubsection{Biomass}

The date palm seeds were washed with deionized water to remove foreign materials and dried in an oven at $105^{\circ} \mathrm{C}$ for 24 $\mathrm{h}$. The dried seeds were crushed and sieved using a standard sieve to collect the precursor with the size lower than $2 \mathrm{~mm}$ and were stored in a desiccator for further use [7].

\subsubsection{Carbonization and Activation}

Carbonization and activation of sieved DS will be carried out simultaneously. Activation will take place by the activated agent $\mathrm{H}_{3} \mathrm{PO}_{4} .30 \mathrm{~g}$ of crushed DS was mixed with $\mathrm{H}_{3} \mathrm{PO}_{4}(60 \%)$ at an impregnation ratio (IR) (grams of $100 \% \mathrm{H}_{3} \mathrm{PO}_{4} /$ gram of dried precursor) of 3.1[7].

\subsection{Calibration Curve}

A $1000 \mathrm{mg} / \mathrm{L}$ stock solution was prepared by dissolving $1 \mathrm{ml}$ of $0.995 \mathrm{~g} / \mathrm{ml} \mathrm{MB}$ dye concentration in $1 \mathrm{~L}$ distilled water. The different concentrations of $\mathrm{MB}$ for the entire study were prepared from that stock solution. The calibration curve was 
prepared between absorbance against the known concentrations of $\mathrm{MB}$ in the aqueous solutions, using a spectrophotometer at an optimum wavelength of $665 \mathrm{~nm}$.

\subsection{Batch Adsorption Processes}

The adsorption experiments were conducted to find the optimum conditions of DSAC to be used. This study shows investigation of three parameters: adsorbent dose, $\mathrm{pH}$ and contact time. There were fixed conditions in each experiment, the solution $\mathrm{pH}$ was 7 except in effect of $\mathrm{pH}$ experiment, the shaking time and speed was 6 hours and 120 RPM, respectively except in contact time influence the contact time was varied. Moreover, all experiments were conducted at room temperature between $22{ }^{\circ} \mathrm{C}$ to 26 ${ }^{\circ} \mathrm{C}$. After shaking, the samples were filtered using filter paper. The final concentration of MB was determined by using the calibration curve. The amount of adsorbed MB onto $\mathrm{AC}, \mathrm{q}_{\mathrm{e}}(\mathrm{mg} / \mathrm{g})$, was found by Equation (1). Comparison between DSAC and CAC were investigated under the same experimental conditions. All the experiments were conducted in duplicate.

$$
\mathrm{q}_{\mathrm{e}}=\left(\left(\mathrm{C}_{0}-\mathrm{C}_{\mathrm{e}}\right) \mathrm{V}\right) / \mathrm{W}
$$

Where $\mathrm{C}_{0}$ and $\mathrm{Ce}$ are the initial and final equilibrium liquid-phase concentrations of $\mathrm{MB}$, respectively $(\mathrm{mg} / \mathrm{L})$, $\mathrm{V}$ the volume of the solution (L), and $\mathrm{W}$ is the weight of the AC used (g).

The percentage removal of $\mathrm{MB}$ from water (R\%) were determined using Equation (2).

$$
\mathrm{R} \%=\left(\left(\mathrm{C}_{0}-\mathrm{C}_{\mathrm{e}}\right) / \mathrm{C}_{0}\right) \times 100
$$

\subsubsection{Effect of adsorbent concentration}

The effect of adsorbent concentration on the adsorption capacity was studied by mixing various amounts of AC i.e. 0.1, 0.2 and $0.3 \mathrm{~g}$ of CAC and DSAC separately to the fixed MB concentration of $300 \mathrm{mg} / \mathrm{L}$, $\mathrm{pH}$ of 7, shaking time of 6 hours with a rotating speed of 120 RPM held in room temperature.

\subsubsection{Effect of $p H$}

The effect of $\mathrm{pH}$ on the $\mathrm{MB}$ adsorption capacity was carried at different MB concentrations of 100, 300 and $500 \mathrm{mg} / \mathrm{L}, 6$ hours equilibrium time, $120 \mathrm{RPM}$, held in room temperature and the adsorbent dose was $0.2 \mathrm{~g}$ of either DSAC or CAC. The initial $\mathrm{pH}$ values were 2 and 10 $\mathrm{pH}$ adjusted by adding a few drops of $0.1 \mathrm{M}$ of $\mathrm{HCl}$ or 0.1 $\mathrm{M}$ of $\mathrm{NaOH}$, respectively.

\subsubsection{Effect of contact time}

The concentration of MB solutions used were 100, 300 and $500 \mathrm{mg} / \mathrm{L}$ at $\mathrm{pH}$ of 7. $0.2 \mathrm{~g}$ of either CAC or DSAC were added. The samples was shacked for 0,1 and 3 hours for each MB concentrations at 120 RPM and held in room temperature $22{ }^{\circ} \mathrm{C}$ to $26^{\circ} \mathrm{C}$.

\section{RESULTS AND DISCUSSIONS}

\subsection{Physical Properties of DSAC Compared with CAC}

The physical properties are listed in Table 1 . The DSAC showing $\mathrm{pH} 6.7$ but $\mathrm{CAC}$ is more than $\mathrm{pH}$ 7. The $\mathrm{CAC}$ showing lesser moisture content than DSAC. On the other hand, ash content of both CAC and DSAC are 5\% and 6\%, respectively which shows that DSAC has slightly more ash content.

Likewise, both activated carbons have almost same bulk density of $0.3 \mathrm{~g} / \mathrm{cm}^{3}$.

\begin{tabular}{lll} 
TABLE 1: PHYSICAL PROPERTIES OF DSAC COMPARED WITH CAC \\
\hline \hline Material & DSAC & CAC \\
\hline $\mathrm{pH}$ & 6.7 & 9.1 \\
Moisture content $\%$ & 7.99 & 4.95 \\
Ash content $\%$ & 6 & 5 \\
Bulk density $\left(\mathrm{g} / \mathrm{cm}^{3}\right)$ & 0.36 & 0.35 \\
\hline \hline
\end{tabular}

\subsection{Batch Adsorption Processes}

\subsubsection{Effect of Adsorbent Concentration}

In order to study the effect of adsorbent dose on MB removal, various amounts of CAC and DSAC were contacted with a fixed initial MB concentration of $300 \mathrm{mg} / \mathrm{l}$, fixed RPM 120 and contact time 6 hours at room temperature. The amount adsorbed at an equilibrium and the percentage removal versus the adsorbent concentration by using CAC and DSAC are shown in Fig. 1 and Fig. 2.

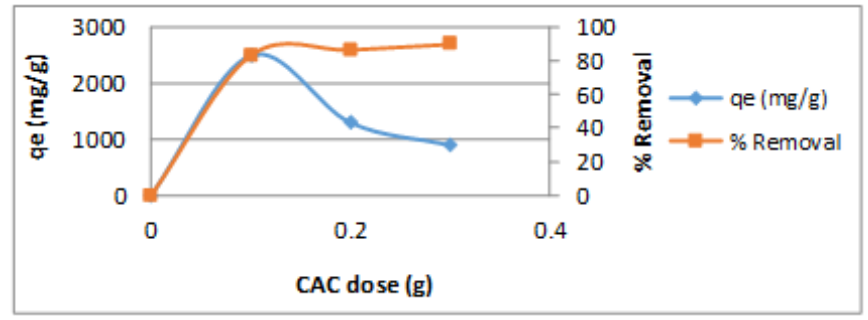

Fig. 1: Effect of CAC dose on MB removal.

It is readily understood that the increase in percentage removal of $\mathrm{MB}$ resulted by the increase of CAC dose. Therefore, increasing CAC dose from 0.1 to $0.3 \mathrm{~g}$ leads to an increase of the adsorption sites and resulting a high percentage removal up to $90 \%$.

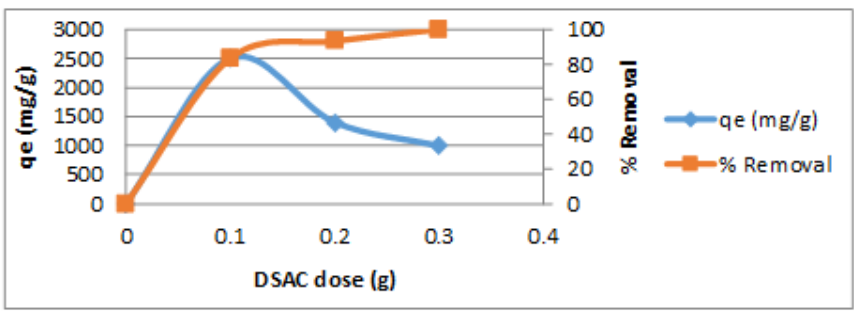

Fig. 2: Effect of DSAC dose on MB removal.

The DSAC dose varied from $0.1 \mathrm{~g}$ to $0.3 \mathrm{~g}$ and it is evident from Fig. 2 that the maximum percentage removal occurred when the concentration of DSAC was $0.3 \mathrm{~g}$. In comparison, DSAC showing $100 \%$ removal which is higher percentage removal of $\mathrm{MB}$ than $\mathrm{CAC}$ at $0.3 \mathrm{~g}$ dose as shown in Fig. 1 and Fig. 2. The optimum DSAC dosage was at $0.3 \mathrm{~g}$. It is because of the increasing the available overall surface area of the DSAC. 
The change of adsorption capacity rate might be due to fact that at first all the adsorbent sites are available and $\mathrm{MB}$ concentration is very high in the solution. Later, adsorption rate was lowered which indicates the possible monolayer formation of $\mathrm{MB}$ on the AC surface [8], [9]. That might indorse to the lack of available active sites required for further uptake after reaching the equilibrium [10].

In the effect of AC dose, the DSAC is fitted with Langmuir isotherm showing regression value 0.9049 . On the other hand, the CAC carbon did not fit with the isotherm for the effect of adsorbent dose. The maximum adsorption capacity $\mathrm{q}_{\mathrm{m}}$ is 2000 $\mathrm{mg} / \mathrm{g}$ as shown in Table 2 . The effect of AC dose 0.1 to $0.3 \mathrm{~g}$ for $300 \mathrm{mg} / \mathrm{L}$ by using Freundlich isotherm is shown. The CAC is fitted with Freundlich isotherm showing regression value 0.9993. On the other hand, the DSAC did not fit with the isotherm for the adsorbent dose effect.

TABLE 2: LANGMUIR AND FREUNDLICH ISOTHERM PARAMETERS FOR MB ADSORPTION BY USING DSAC AND CAC ON THE EFFECT OF ADSORPTION DOSE.

\begin{tabular}{|c|c|c|c|c|c|c|c|}
\hline \multirow[t]{2}{*}{$\mathrm{AC}$} & \multirow[t]{2}{*}{ Characteristic } & \multicolumn{3}{|c|}{ Langmuir isotherm } & \multicolumn{3}{|c|}{ Freundlich isotherm } \\
\hline & & $\begin{array}{l}\mathrm{q}_{\mathrm{m}} \\
(\mathrm{mg} / \mathrm{g})\end{array}$ & $\begin{array}{l}\mathrm{K}_{\mathrm{L}} \\
(\mathrm{L} / \mathrm{mg})\end{array}$ & $\mathrm{R}^{2}$ & $\begin{array}{l}\mathrm{K}_{\mathrm{F}} \\
(\mathrm{mg} / \mathrm{g})(\mathrm{L} / \mathrm{mg})^{1 / \mathrm{n}}\end{array}$ & $1 / \mathrm{n}$ & $\mathrm{R}^{2}$ \\
\hline$\overline{\mathrm{CAC}}$ & Adsorption dose & 2000 & 0.084746 & 0.5188 & -8.51719 & 1.9809 & 0.9993 \\
\hline$\overline{\text { DSAC }}$ & Adsorption dose & 2500 & $7.66 \mathrm{E}-07$ & 0.9049 & 0.414755 & 1.1627 & 0.4104 \\
\hline
\end{tabular}

\subsubsection{Effect of $p H$}

The $\mathrm{pH}$ of dye solution is an important influencing factor for the adsorption of MB onto CAC and DSAC. The effect of initial $\mathrm{pH}$ of the solution on the uptake of MB by CAC and DSAC were studied at $\mathrm{pH} 2$ and 10 . The $\mathrm{MB}$ concentrations used were 100,300 and $500 \mathrm{mg} / \mathrm{L}$.

TABLE 3: EFFECT OF PH ON ADSORPTION CAPACITY AND PERCENTAGE REMOVAL OF CAC FOR 100, 300 AND 500 MG/L OF MB

\begin{tabular}{l|lll}
\hline \multirow{2}{*}{$\mathrm{pH}$} & \multicolumn{1}{c}{$\begin{array}{c}\text { MB } \\
(\mathrm{mg} / \mathrm{L})\end{array}$} & qe (mg/g) & \% Removal \\
\hline \multirow{3}{*}{2} & 100 & 400 & 80 \\
\cline { 2 - 4 } & 300 & 1400 & 93.33 \\
\cline { 2 - 4 } & 500 & 2300 & 92 \\
\hline \multirow{4}{*}{10} & 100 & 400 & 80 \\
\cline { 2 - 4 } & 300 & 1400 & 93.33 \\
\cline { 2 - 4 } & 500 & 2400 & 96 \\
\hline
\end{tabular}

Table 3 shows that the adsorption capacity of methylene blue at 100 and $300 \mathrm{mg} / \mathrm{L}$ has no change at acidic and alkaline rate. There was a slight increase in the adsorption capacity at $500 \mathrm{mg} / \mathrm{L}$ when $\mathrm{pH} 10$. The best percentage removal was at $\mathrm{pH}$ 10 with $500 \mathrm{mg} / \mathrm{L} \mathrm{MB}$ concentration. Therefore, the $\mathrm{pH}$ is not influencing the adsorption rate for low dye solution concentrations but for higher $\mathrm{MB}$ concentration

The DSAC was used as an adsorbent to remove methylene blue by using pH 2 and 10 shown in Table 4. The maximum MB removal was observed at $\mathrm{pH} 10$. When the $\mathrm{MB}$ concentration at
$\mathrm{pH} 10$ were 100 and $300 \mathrm{mg} / \mathrm{L}$ the percentage removal were $100 \%$ for both concentrations. DSAC showing better removal of $\mathrm{MB}$ from the solution in the alkaline range than in the acidic range. It is more efficient than $\mathrm{CAC}$ at the alkaline range. Therefore, when $\mathrm{pH}$ of dye solution was increased, the surface of AC became negatively charged, thus resulting the electrostatic attraction between the dye cation $\mathrm{MB}^{+}$and negatively charged DSAC. Similar results were obtained by many researchers [8], [11], [12], [13] and [14] on different AC based adsorbents.

TABLE 4: EFFECT OF PH ON ADSORPTION CAPACITY AND PERCENTAGE REMOVAL OF DSAC FOR 100, 300 AND 500 MG/L OF MB.

\begin{tabular}{c|lll}
\hline \multirow{2}{*}{$\mathrm{pH}$} & \begin{tabular}{c}
$\mathrm{MB}$ \\
\multicolumn{2}{c}{$(\mathrm{mg} / \mathrm{L})$}
\end{tabular} & qe ( mg/g) & \% Removal \\
\hline \multirow{3}{*}{2} & 100 & 250 & 50 \\
\cline { 2 - 4 } & 300 & 1150 & 76.66 \\
\cline { 2 - 4 } & 500 & 2050 & 82 \\
\hline \multirow{3}{*}{10} & 100 & 500 & 100 \\
\cline { 2 - 4 } & 300 & 1500 & 100 \\
\cline { 2 - 4 } & 500 & 2400 & 96 \\
\hline
\end{tabular}

The Langmuir isotherm fits with DSAC at $10 \mathrm{pH}$ at best correlation coefficient $\mathrm{R}^{2}=1$. However, it didn't fit with DSAC at $2 \mathrm{pH}$ and $\mathrm{CAC}$ at 2 and $10 \mathrm{pH}$. The $\mathrm{pH}$ effect on the CAC and DSAC had been found and implemented on the Freundlich isotherm at $300 \mathrm{mg} / \mathrm{L} \mathrm{MB}$ concentration. It is noticeable from Table 5 that both AC at different $\mathrm{pH}$ fitted with the Freundlich isotherm except DSAC at $10 \mathrm{pH}$. The CAC shows $\mathrm{R}^{2}>0.95$, which is best fitted compared with DSAC data. 
TABLE 5: LANGMUIR AND FREUNDLICH ISOTHERM PARAMETERS For MB AdSORPTION By USING DSAC AND CAC ON THE EFFECT OF PH.

\begin{tabular}{|c|c|c|c|c|c|c|c|}
\hline \multirow[t]{2}{*}{$\mathrm{pH}$} & \multirow[t]{2}{*}{$\mathrm{AC}$} & \multicolumn{3}{|c|}{ Langmuir isotherm } & \multicolumn{3}{|c|}{ Freundlich isotherm } \\
\hline & & $\mathrm{q}_{\mathrm{m}}(\mathrm{mg} / \mathrm{g})$ & $\mathrm{K}_{\mathrm{L}}(\mathrm{L} / \mathrm{mg})$ & $\mathrm{R}^{2}$ & $\mathrm{~K}_{\mathrm{F}}(\mathrm{mg} / \mathrm{g})(\mathrm{L} / \mathrm{mg})^{1 / n}$ & $1 / \mathrm{n}$ & $\mathrm{R}^{2}$ \\
\hline \multirow[t]{2}{*}{2} & CAC & 2500 & 0.03418 & 0.113 & -3.78539 & 2.1453 & 0.9771 \\
\hline & DSAC & 2500 & 0.02564 & 0.0488 & -3.32424 & 1.6213 & 0.9785 \\
\hline \multirow[t]{2}{*}{10} & $\mathrm{CAC}$ & 833.33 & $1.2 \mathrm{E}+14$ & 0.302 & -34.5388 & 2.3388 & 0.9561 \\
\hline & DSAC & 2500 & $1 \mathrm{E}+15$ & 1 & 0.672128 & 1.0929 & 0.2054 \\
\hline
\end{tabular}

\subsubsection{Effect of Contact Time}

The relation between adsorption capacity of $\mathrm{MB}$ and contact time using CAC and DSAC as adsorbents were investigated to identify the rate of MB removal as shown in Fig. 3 and Fig. 4, respectively.

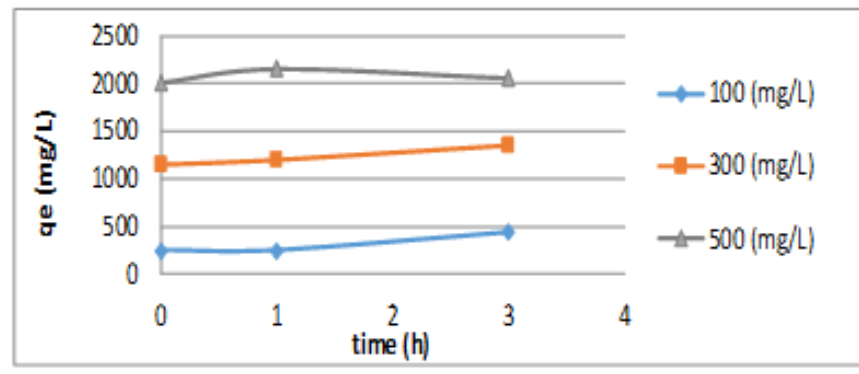

Fig. 3: Effect of contact time on adsorption capacity of CAC for 100, 300 and $500 \mathrm{mg} / \mathrm{L}$ of $\mathrm{MB}$

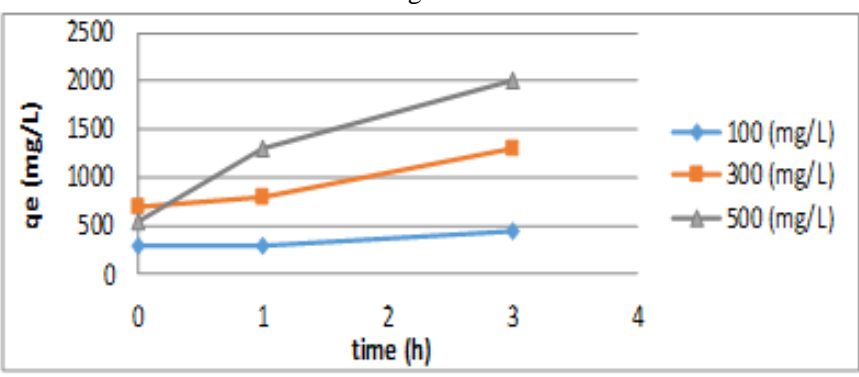

Fig. 4: Effect of contact time on adsorption capacity of DSAC for 100, 300 and $500 \mathrm{mg} / \mathrm{L}$ of $\mathrm{MB}$

The effect of contact time was first investigated to determine the equilibrium time for $\mathrm{MB}$ adsorption onto $\mathrm{CAC}$ at room temperature as shown in Fig. 3. The concentrations of $\mathrm{MB}$ solutions ranged of 100,300 and $500 \mathrm{mg} / \mathrm{L}$ were used. The adsorption capacity of $\mathrm{MB}$ increased with the increase of contact time for both concentrations 100 and $300 \mathrm{mg} / \mathrm{L}$.
However, when the concentration of MB was $500 \mathrm{mg} / \mathrm{L}$ the adsorption capacity increased to its maximum at $1 \mathrm{~h}$ contact time then it slightly decreased at $3 \mathrm{~h}$ contact time.

Undoubtedly, the adsorption capacity increased with the increase of contact time for different concentrations of $\mathrm{MB}$ using DSAC at varies concentrations ranged of 100 to 500 $(\mathrm{mg} / \mathrm{L})$ which is shown in Fig. 4. The adsorption capacity of zero hour contact time was taken immediately after adding the AC. The shaking time was about 15 seconds. Both AC's showing attributable to the large number of sites available for adsorption.

The ability of CAC to adsorb MB decreased in $500 \mathrm{mg} / \mathrm{L}, 3$ hour contact time because binding of function groups on the surface of CAC and MB was weak because the longer the contact time of adsorption, the more collision between particle of CAC and MB appeared [15]. There were no much difference in adsorption capacities of DSAC in low concentrations of MB during zero and 1 hour contact time. That was because the low amount of MB molecules in the solution, so it took longer time to trap in the DSAC pores. The optimum contact time of DSAC at 3 hour for all the concentration because it has the highest adsorption rates through all the concentrations. At 3 hour contact time, it reached to optimum contact time of $\mathrm{MB}$ adsorption. It showed that the amount of $\mathrm{MB}$ adsorbed by DSAC and remained in the solution were in equilibrium [15].

The Langmuir and Freundlich isotherms for CAC and DSAC for the effect of contact time with different $\mathrm{MB}$ concentrations is show in Table 6. It fits with adsorption data at 0 hour contact time $\mathrm{R}^{2}>0.95$ for $\mathrm{DSAC}$ and $\mathrm{R}^{2}>0.8$ at 3 hour contact time for CAC. The $\mathrm{q}_{\mathrm{m}}$ of both CAC and DSAC are 2500 $\mathrm{mg} / \mathrm{g}$ at 3 hour contact time. All adsorption data fits with the Fruendlich isotherm $\mathrm{R}^{2} \geq 9.0$. According to Table 6 , the Freundlich isotherm best fits with all contact time experimental data.

TABLE 6: LANGMUIR AND FREUNDLICH ISOTHERM PARAMETERS FOR MB ADSORPTION BY USING DSAC AND CAC ON THE EFFECT OF CONTACT TIME.

\begin{tabular}{|c|c|c|c|c|c|c|c|}
\hline \multirow[t]{3}{*}{ Isotherm } & \multirow[t]{3}{*}{ Parameter } & \multicolumn{3}{|c|}{$\mathrm{CAC}$} & \multicolumn{3}{|c|}{ DSAC } \\
\hline & & \multicolumn{3}{|c|}{ Contact time (hour) } & \multicolumn{3}{|c|}{ Contact time (hour) } \\
\hline & & 0 & 1 & 3 & 0 & 1 & 3 \\
\hline \multirow{3}{*}{ Langmuir } & $\mathrm{q}_{\mathrm{m}}(\mathrm{mg} / \mathrm{g})$ & 2500 & 1111.11 & 2500 & 588.23 & 1666.66 & 2500 \\
\hline & $\mathrm{K}_{\mathrm{L}}(\mathrm{L} / \mathrm{mg})$ & 0.0072 & 0.0291 & 0.0444 & 0.1517 & 0.0666 & 0.0408 \\
\hline & $\mathrm{R}^{2}$ & 0.04 & 0.0961 & 0.825 & 0.9756 & 0.6641 & 0.8573 \\
\hline \multirow{3}{*}{ Freundlich } & $\begin{array}{c}\mathrm{K}_{\mathrm{F}} \\
(\mathrm{mg} / \mathrm{g})(\mathrm{L} / \mathrm{mg})^{1 / \mathrm{n}}\end{array}$ & -3.3843 & -3.5439 & -1.1132 & -1.6291 & -2.5096 & -1.0873 \\
\hline & $1 / \mathrm{n}$ & 1.6044 & 1.6769 & 1.7559 & 1.1377 & 1.333 & 1.6774 \\
\hline & $\mathrm{R}^{2}$ & 0.9822 & 0.9616 & 0.9052 & 0.9214 & 0.9846 & 0.9035 \\
\hline
\end{tabular}




\section{CONCLUSION}

In the present study, optimization of $\mathrm{MB}$ removal from aqueous solution using DSAC prepared by chemical activation using phosphoric acid $\left(\mathrm{H}_{3} \mathrm{PO}_{2}\right)$ as activated agent was investigated. The DSAC was compared with CAC. The physical properties and influence of adsorbent dose, $\mathrm{pH}$ and contact time of both ACs were determined. In conclusions, the characteristics of the prepared DSAC were $\mathrm{pH} 6.7$, moisture content $7.99 \%$, ash content $6 \%$ and bulk density $0.36 \mathrm{~g} / \mathrm{cm}^{3}$ can be replaced with $\mathrm{CAC}$. The percentage removal of $\mathrm{MB}$ by DSAC was higher than CAC, $100 \%$ and $90 \%$ respectively i.e. with optimum dosage $0.3 \mathrm{~g}$ for $300 \mathrm{mg} / \mathrm{L} \mathrm{MB}$ concentration. The optimum $\mathrm{pH}$ and contact time of DSAC was found to be $\mathrm{pH}$ 10 and 3 hours respectively. Moreover, the $\mathrm{pH} 10$ showing optimum percentage removal 100, 100 and $96 \%$ for 100,300 and $500 \mathrm{mg} / \mathrm{L}$ respectively. The optimum contact time was $3 \mathrm{~h}$ showing percentage removal 90,86 and $80 \%$ for 100,300 and $500 \mathrm{mg} / \mathrm{L} \mathrm{MB}$ concentrations respectively. All adsorption data from CAC are best fits with Freundlich isotherm. However, DSAC adsorption data did not fit with one isotherm only but it fits with both Langmuir and Freundlich isotherms in different batch experiments. The adsorbent dose and $10 \mathrm{pH}$ data fits with Langmuir isotherm and didn't fit with Fruendlich isotherm and via versa with $\mathrm{pH}$ 2. Moreover, the DSAC best fits with Freundlich isotherm in contact time adsorption data. Finally, from these results understood that DSAC can be replaced with $\mathrm{CAC}$ using the optimum conditions for best results.

\section{REFERENCES}

[1] Chafia Bouchelta et al. (2008). Preparation and characterization of activated carbon from date stones. Science direct.

[2] M.K. Sharma, R.C. Sobti. (2000). Rec effect of certain textile dyes in Bacillus subtilis. 27-38. https://doi.org/10.1016/s1383-5718(99)00201-6

[3] Kayode Adesina Adegoke, Olugbenga Solomon. (2015). Dye sequestration using agricultural wastes as adsorbents. Water Resources and Industry. https://doi.org/10.1016/j.wri.2015.09.002

[4] ASTM. (1996). American Society for Testing and Materials Annual Book of ASTM Standard. Philadelphia PA.

[5] Test, A. S. (1991). Methods for moisture in activated carbon. Philadelphia: PA: ASTM Committee on Standards.

[6] Abdul Halim Abdullah et al. (2000). Preparation and Characterization of Activated Carbon from Gelam Wood Bark (Melaleuca cajuputi). Malaysian Journal of Analytical Sciences, 68.

[7] K. Suresh Kumar Reddy et al. (2012). A comparison of microstructure and adsorption characteristics of activated carbons by $\mathrm{CO} 2$ and $\mathrm{H} 3 \mathrm{PO} 4$ activation from date palm pits. NEW CARBON MATERIALS, 344-351. https://doi.org/10.1016/S1872-5805(12)60020-1

[8] Abde et al. (2009). Adsorption, kinetic and equilibrium studies on removal of basic dye from aqueous solutions using hydrolyzed oak sawdust. Desalin. Water Treat, 252-268.

[9] Ahmed El Nemr et al. (2009). Removal of direct blue-86 from aqueous solution by new activated carbon developed from orange peel. Journal of Hazardous Materials, 102-110. https://doi.org/10.1016/j.jhazmat.2008.03.060

[10] Sha Liang et al. (2010). Isotherms, kinetics and thermodynamic studies of adsorption of $\mathrm{Cu} 2+$ from aqueous solutions by $\mathrm{Mg} 2+/ \mathrm{K}+$ type orange peel adsorbents. Journal of Hazardous Materials, 756-762. https://doi.org/10.1016/j.jhazmat.2009.09.116

[11] Malik, P. (2003). Use of activated carbons prepared from sawdust and rice-husk for adsorption of acid dyes: a case study of Acid Yellow 36. Dyes and Pigments, 239-249.
https://doi.org/10.1016/S0143-7208(02)00159-6

[12] Md. Azharul Islam et al. (2015). Mesoporous and adsorptive properties of palm date seed activated carbon prepared via sequential hydrothermal carbonization and sodium hydroxide activation. Chemical Engineering Journal.

[13] A.E. Pirbazari et al. (2014). Alkali treated Foumanat tea waste as an efficient adsorbent for methylene blue adsorption from aqueous solution. Water Resour, 64-80. https://doi.org/10.1016/j.wri.2014.07.003

[14] Wanqi Li et al. (2011). Preparation and utilization of sludge-based activated carbon for the adsorption of dyes from aqueous solutions. Chem. Eng. J, 320-327. https://doi.org/10.1016/j.cej.2011.04.012

[15] Ahmad Said et al. (2014). The Effect of Contact Time and $\mathrm{pH}$ on Methylene Blue Removal by Volcanic Ash. Int'l Conference on Chemical, Biological, and Environmental Sciences, (pp. 11-13). Kuala Lumpur. 